\title{
APPLICATION OF THE ADAPTIVE REUSE POTENTIAL MODEL IN HONG KONG: A CASE STUDY OF LUI SENG CHUN
}

\author{
Craig LANGSTON ${ }^{1}$ and Li-Yin SHEN 2 $ه$ \\ 1 Visiting Professor, Department of Building and Real Estate, The Hong Kong Polytechnic \\ University, Hung Hom, Kowloon, Hong Kong SAR, China \\ E-mail: craigl@deakin.edu.au \\ 2 Department of Building and Real Estate, The Hong Kong Polytechnic University, Hung Hom, \\ Kowloon, Hong Kong SAR, China \\ E-mail: bsshen@polyu.edu.hk
}

Received 12 July 2007; accepted 10 October 2007

\begin{abstract}
There is an increasing complexity and interplay between all of the issues associated with property portfolio decisions. This paper explores the relationships between financial, environmental and social parameters associated with building adaptive reuse by way of a case study. A new model predicting adaptive reuse potential is applied to a heritage building in Hong Kong known as Lui Seng Chun. Such application can assist in the transformation of the building and property industry towards more sustainable practices, strategies and outcomes, by providing a means by which the industry can identify and rank existing buildings that have high potential for adaptive reuse. In Hong Kong's case it provides an ability for sustainable, responsive energy and natural resource management by allowing issues regarding excessive and inappropriate resource use to be identified and assessed, and appropriate management strategies to be implemented. Given the building's current age and condition, Lui Seng Chun has at least 25 years of physical life remaining. The further application of a multi-criteria sustainability evaluation tool supports the conclusion that an adaptive reuse strategy for this building will make a demonstrable contribution to the economic, social and environmental amenity of Hong Kong. The application of these techniques to other buildings with significant "embedded physical life" is highly recommended.
\end{abstract}

KEYWORDS: Adaptive reuse; Sustainability; Preservation; Heritage; Multi-criteria analysis

\section{INTRODUCTION}

The number of new residential completions in 2006 was 16,579 , adding $1.5 \%$ to the stock of residential units in Hong Kong (including Kowloon and the New Territories) of 1,053,246 units in 2005 (RVD, 2007: Table 2). Office space completion was unusually low at 108,200 $\mathrm{m} 2$, adding just $1.1 \%$ to the 2005 stock of $9,769,700 \mathrm{~m}^{2}$ (RVD, 2007: Table 18). Commercial space rose $1.9 \%$ or $182,800 \mathrm{~m}^{2}$ in 2006 from the previous stock of 9,522,400 $\mathrm{m}^{2}$ (RVD, 2007: Table 27). Industrial space (comprising private flatted factories, industrial/office, specialized factories and storage) rose $43,500 \mathrm{~m}^{2}$ from $24,635,500 \mathrm{~m}^{2}$ in 2005 - just $0.18 \%$ in 2006 (RVD, 2007: Tables 33, 40, 43 and 45).

The construction industry in Hong Kong normally contributes between 4 and $8 \%$ of national GDP; an average of $5.85 \%$ per annum over the period 1992-2005 inclusive (http:// www.censtatd.gov.hk/). The value of annual

International Journal of Strategic Property Management ISSN 1648-715X print / ISSN 1648-9179 online (c) 2007 Vilnius Gediminas Technical University http://www.ijspm.vgtu.lt 
activity is about HK $\$ 90$ billion (2006) of which $46.3 \%$ is new private and public construction sites and the remainder is minor new construction work and renovation activities at existing building locations. At a global level, buildings consume $32 \%$ of world resources, $12 \%$ of water consumption, $40 \%$ of waste to landfill, and $40 \%$ of air and greenhouse gas emissions (Harrington et al., 1999; Rees, 1999: Langston and Ding, 2001; Meillaud et al., 2005).

A simple calculation shows that new construction adds less than $2 \%$ per annum to the built environment stock in Hong Kong. Yet greenhouse gas emissions (GGE) in Hong Kong are nearing 50 million tonnes $\left(\mathrm{CO}_{2}\right.$-equivalent) per annum and rising (http://www.epd.gov.hk/ ). Expressed in terms of emissions per square metre, Hong Kong is considered to be the largest producer of GGE in the world (The Standard, 2007). So it will take perhaps up to a century before the energy efficient strategies of new building construction can make any significant difference to the greenhouse gas reduction targets of the Hong Kong Government. Energy efficient design should therefore be focused on retrofit of existing buildings rather than demolition and new construction. We must better look after what we have (Ball, 1999).

Existing buildings that are obsolete or rapidly approaching disuse and potential demolition are a 'mine' of raw materials for new projects; a concept described by Chusid (1993) as 'urban ore'. Even more effective, rather than extracting these raw materials during demolition or deconstruction and assigning them to new applications, is to leave the basic structure and fabric of the building intact, and change its use. This approach is called 'adaptive reuse'. Breathing 'new life' into existing buildings carries with it environmental and social benefits and helps to retain our national heritage. To date, a focus on economic factors alone has contributed to destruction of buildings well short of their physical lives.
One in eleven of Hong Kong's historic buildings have been torn down since 1980. The Antiquities Advisory Board revealed that 54 out of 607 buildings it had listed since it was set up in 1980 have been demolished. There are now 496 graded historic buildings and 81 declared monuments left in Hong Kong. But graded sites currently have no legal protection (Sunday Morning Post, 2007).

This paper aims to extend previous research concerning an adaptive reuse potential model by applying it for the first time to a potential adaptive reuse project in Hong Kong. Specifically, the purposes are to:

1. demonstrate the application of the model in identifying projects with potential for adaptive reuse, and

2. evaluate a project of high potential using a multi-criteria approach to determine if actions to preserve and revitalize it are warranted.

To achieve these aims a case study of Lui Seng Chun in the Mong Kok district of Hong Kong is explored in detail. This building was constructed in 1932 and was donated to the HKSAR Government in 2003. It is currently under the care of the Antiquities and Monuments Office (AMO) awaiting further action. Community consultation concerning this project is underway.

\section{BACKGROUND}

\subsection{Adaptive reuse}

Adaptive reuse is a special form of refurbishment that poses quite difficult challenges for designers. Changing the class (functional classification) of a building will introduce new regulatory conditions and perhaps require zoning consent. There are clear economic, environmental and social benefits that can make this option attractive to developers. In some cases increases in floor space ratios can be obtained and concessions received for pursuing 
government policy directions by regenerating derelict public assets. In recent years redundant city office buildings have been converted into high quality residential apartments, bringing people back to cities and in the process revitalizing them. In Hong Kong, the Urban Renewal Authority plays an important role in overseeing such projects (http://www.ura. org.hk).

Adaptive reuse has been successfully applied in many types of facilities, including defence estates (e.g. Doak, 1999; Van Driesche and Lane, 2002), airfields (e.g. Gallent et al., 2000), government buildings (e.g. Abbotts et al., 2003), and industrial buildings (e.g. Ball, 1999; Anon., 2006). Around the world, adaptive reuse of historic buildings is seen as fundamental to sound government policy and sustainable development - e.g. in Atlanta, US (Newman, 2001), Canada (Brandt, 2006), Hong Kong (Poon, 2001), North Africa (Leone, 2003) and Australia (Maggs, 1999; McLaren, 1996).

Adaptive reuse can be quite dramatic. For example, conversion of disused industrial factories into shopping centres or churches into restaurants is possible. Property managers should be conscious of adaptive reuse solutions to redundant space and continually think about more productive uses for existing premises.

Newman (2001) discussed various political issues relating to historic building reuse, noting that preservation in many cases was predicated on reuse, finding a balance between the interests of developers, property owners and preservation advocates. Stakeholder involvement is critical. Ball (1999) found that persistently vacant buildings are less able to be reused than newly vacated premises. So timeliness is an important characteristic in identifying adaptive reuse potential.

In making decisions about whether to reuse a building or to demolish and rebuild, the energy and waste disposal costs of new action usually do not include all the environmental and social costs (Guy and Kibert, 1998). Un- masking these costs can provide strong incentives for a transition to more sustainable energy use, less profligate use of new materials, and greater use of existing building stock. Refurbishment is also a greater employment generator than new construction. According to Tully (1993), refurbishment generates 25\% more employment than new building construction per square metre of floor space as a result of the typical labour-intensive activities involved in renovation.

\subsection{Adaptive reuse potential model}

The conceptual framework of an approach to identify and rank adaptive reuse potential (ARP) for existing buildings is described in Langston et al., (2007). The model requires an estimate of the expected physical life of the building and the current age of the building, both reported in years. It also requires an assessment of physical, economic, functional, technological, social and legal obsolescence. Obsolescence is advanced as a suitable method to reduce expected physical life in order to calculate objectively the useful life of the building. An index of reuse potential expressed as a percentage is calculated. Existing buildings in an organization's portfolio, or existing buildings across a city or territory, can therefore be ranked according to the potential they offer for adaptive reuse. Where the current building age is close to and less than the useful life, the model identifies that planning should commence.

Useful life is determined from Equation 1. The form of the equation applies the notion that useful life is indeed discounted physical life, and uses the long-established method of discount as its basis, where the "discount rate" is taken as the sum of the obsolescence factors per annum (i.e. factors are divided by $L_{p}$ ). 


$$
L_{u}=\frac{L_{p}}{\left(1+\sum_{i=1}^{6} O_{i}\right)^{L_{p}}} .
$$

where: $L_{p}=$ physical life (years); $O_{1}=$ physical obsolescence (\% as decimal p.a.); $\mathrm{O}_{2}=$ economic obsolescence (\% as decimal p.a.); $\mathrm{O}_{3}=$ functional obsolescence ( $\%$ as decimal p.a.); $\mathrm{O}_{4}=$ technical obsolescence ( $\%$ as decimal p.a.); $O_{5}=$ social obsolescence (\% as decimal p.a.); $\mathrm{O}_{6}=$ legal obsolescence (\% as decimal p.a.).

Using this approach, a building receiving the maximum reduction for each type of obsolescence will have a useful life calculated at about one-third of its physical life.

An index is calculated that prioritizes buildings according to their potential for adaptive reuse, and expresses this potential as a percentage. Buildings with a high index possess the highest potential, while buildings with a zero index have no potential. The algorithm is summarized in Figure 1.
Values for $E L_{u}$ (effective useful life), $E L_{b}$ (effective building age) and $E L_{p}$ (effective physical life) are respectively determined by multiplying $L_{u}, L_{b}$ and $L_{p}$ by 100 and dividing by $L_{p}$, which enables a maximum scale for $x$ and $y$ axes of 100. $L_{b}$ is defined as the current age of the building (in years).

The feasible zone for the $A R P$ is defined by the shaded area under the curve (where $x$ is in the range 0 to 100) as defined by Equation 2 , and takes the form of a negative exponential.

$$
y=100-\frac{x^{2}}{100} .
$$

The line of increasing adaptive reuse potential and the line of decreasing adaptive reuse potential are given by Equation 3 and 4 respectively.

$$
A R P_{\text {(increasing) }}=\frac{100-\frac{E L_{u}{ }^{2}}{100} \cdot E L_{b}}{E L_{u}} ;
$$

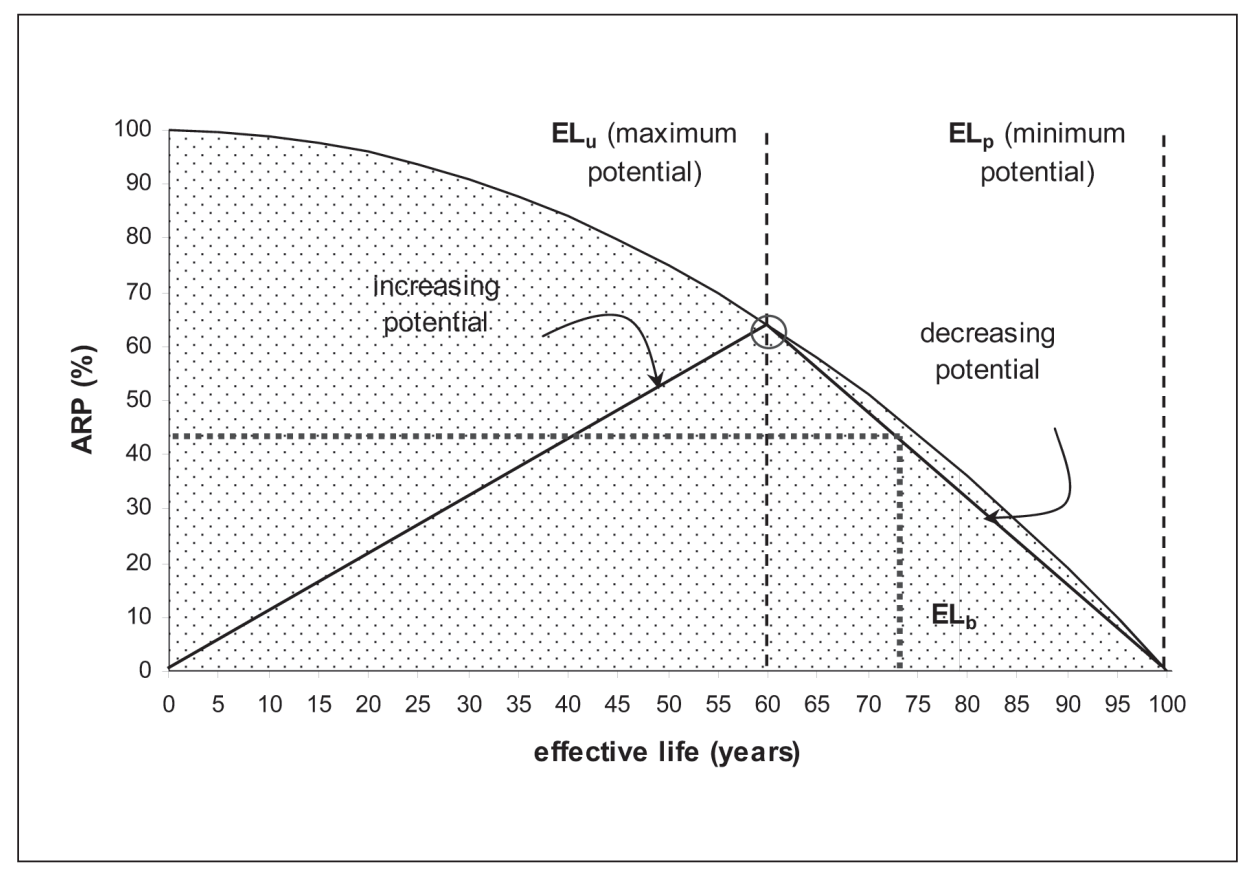

Figure 1. ARP model concept 


$$
A R P_{\text {(decreasing) }}=\frac{100-\frac{E L_{u}{ }^{2}}{100} \cdot\left(100-E L_{b}\right)}{100-E L_{u}} ;
$$

where: $E L_{u}$ - effective useful life (years); $L_{b}$ - effective building age (years).

Values of $A R P$ above 50 are considered to have high potential for adaptive reuse, while values in the range 20-49 show moderate potential, and values in the range 1-19 show low potential. An $A R P$ value of zero has no potential. When $E L_{u}$ and $E L_{b}$ equal, the maximum $A R P$ value possible for that stage of the building's life cycle is generated. Values above 85 would suggest strongly that planning activities should commence. ARP values access potential for adaptive reuse independent of ascribed heritage or cultural significance that often arise with age.

\subsection{Multi-criteria assessment}

The question remains, however, about what to do with the rankings. Theoretically the rankings indicate buildings that have a high potential for adaptive reuse, based largely on the embedded physical life that remains after the original useful life has expired. This potential is influenced to some extent by the current age of the building. Decisions about reuse must take account of economic, environmental and social benefits if appropriate interpretation of a building's contribution is to be realized. A focus on monetary issues alone, as is quite common in Hong Kong, will lead to bias in decision-making when wider social and environmental issues are relevant.

The identification of value for money on development projects is indeed commonly related to monetary return. But other issues are also relevant, particularly for social infrastructure projects, and some are becoming increasingly significant. For example, issues such as functionality and resource efficiency are vital to the assessment of sustainable development in the wider social context. Since no single criterion can adequately address all the issues involved in complex decisions of this type, a multi-criteria approach to decision making offers considerable advantage.

Social costs and benefits (including those related to environment impact and heritage) need to be integrated into the evaluation and a strategy developed that gives these factors proper consideration in practice. Social costs and benefits should not be discounted alongside conventional cash flows as they bear little relationship to financial matters and do not reduce in importance exponentially over time. In fact, future generations may value environmental issues more highly than the present generation (Langston, 2005).

Alternatives have been developed to replace cost-benefit analysis completely with other techniques that do not require environmental or social costs and benefits to be monetarized. Cost effectiveness analysis and environmental impact assessment are leading solutions in this respect. Others have suggested supplementing cost-benefit analysis with a technique that can measure environmental costs in different ways (Nijkamp et al., 1990; Abelson, 1996; Van Pelt, 1993; and Hanley, 1992).

When evaluating projects and facilities it is important to take a holistic view. John Elkington proposed the triple bottom line concept in 1997 (cited in Kenny and Meadowcroft, 1999). This approach demands consideration of financial, social and environmental parameters (known as the 3Ps of profit, people and places). It is an approach that has received widespread international recognition and adoption (Beinat and Nijkamp, 1998; Bell and Morse, 1999; Langston and Lauge-Kristensen, 2002; McCornell and Abel, 1999). Some people advocate a fourth parameter (ethics) to deal with issues of intergenerational equity. Such methodologies are examples of multi-criteria decision analysis.

Several methodologies and algorithms have 
been developed to provide decision makers with advice about selection, but they are either complicated or expensive to use (Vignes, 1999; and Khan et al., 2002), or narrowly focused (Chen and Huang, 2001). Moreover, in the traditional decision making process, weighting each criterion is a very difficult process and depends heavily on the personal preference of the decision maker. Various criteria can be measured using an appropriately matched methodology and assembled into a single decision model.

SINDEX is a recent software tool that uses multiple criteria to calculate a sustainability index, and has the potential to completely replace conventional net present value methodologies for ranking and selecting projects. Based on an extensive literature review, industry survey and testing in the field (Ding and Langston, 2002), key objectives were narrowed down and grouped into four criteria and identified as maximising wealth (investment return); maximising utility (functional performance); minimising resources (energy usage), and minimising impact (loss of habitat). The basis of the SINDEX methodology is normalized weighted criteria and is further described in Ding and Langston (2004).

Wealth is measured as a benefit-cost ratio and includes all aspects of life cycle cost (e.g. maintenance, durability, future replacement). A weighted evaluation matrix (criteria and performance) is used to measure utility in a quantitative manner. Energy usage (including both embodied and operating energy) is measured as annualised GJ or GJ $/ \mathrm{m}^{2}$. Assessment scorecards (questionnaires) are used to quantify loss of habitat (both environmental and cultural) and can be expressed as a risk probability factor. When all four criteria are combined, an indexing algorithm (formula) is created that rank projects and facilities on their contribution to sustainable development. The algorithm is termed the "sustainability index" (Langston and Ding, 2001). Each criterion is measured in different units and later normal- ized and combined. Criteria will be left as equally weighted.

The application of the ARP model and the use of SINDEX to verify that such potential can be realized using a range of financial, social and environmental criteria is to be demonstrated for an actual project in Hong Kong.

\section{CASE STUDY: LUI SENG CHUN}

\subsection{History}

Lui Seng Chun is located at 119 Lai Chi Kok Road in the Mong Kok district, one of the most densely populated areas of Hong Kong. The historic building was designed as a Chinese shophouse over four levels, exhibiting wide veranda (external corridors) on most facades. Background information about Lui Seng Chun can be found at http://www.amo.gov.hk/ en/built_reuse1.php, and together with other facts available on the public record, has been used to introduce this case study.

Mr. Lui Leung (alias Lui Hung Wai), the first owner of Lui Seng Chun, was born in Taishan County of the Guangdong Province. Upon his arrival in Hong Kong, he became actively engaged in transport and trading businesses. He was one of the founders of the Kowloon Motor Bus Company (1933) Ltd. In 1929, Mr. Lui purchased land in Lai Chi Kok Road from the Government and appointed Mr. Bourne, a local architect who specialized in designing shophouses, to construct Lui Seng Chun. The construction work was completed by 1932 . The ground floor of the building was occupied by a Chinese bone-setting medicine shop named "Lui Seng Chun", while the upper floors became living quarters for the members of Lui's family. The name "Lui Seng Chun" was derived from a pair of rhymed couplets, implying Lui's medicine could bring a patient back to life.

Mr. Lui Leung passed away in 1944 and the shop was closed down a few years later. 
The building was subsequently used as accommodation and let out as tailor shops. In 2000, the Lui family proposed to the Antiquities and Monuments Office to donate the building to the Government. The transfer of the building was accomplished in October 2003.

Lui Seng Chun not only bears witness to the history of a well-known family in Hong Kong, but also illustrates the past community life, economic activities and architecture of the territory. Figure 2 is a recent photograph.

Being a four-storey building, Lui Seng Chun is a typical "Kee-lau" or "Tong-lau" (Chinese tenement). This type of two-to-four-storey residence integrating Chinese and Western architectural styles was very popular in the early 20th century.

Lui Seng Chun reflects the Neo-Classical style that is characterized by a square-shaped frame and a row of decorative balustrades in front. The deep verandahs help prevent rain from flooding the house, block sunlight and keep the indoor area cool. This together with the stone plaque marked with the name of the medicine shop installed at the top of the building are all typical architectural features of prewar Chinese tenements. The main facade of the building was lavishly decorated with classical Italianate designs, one of which is the "broken pediment" at the shop. The curved front elevation was designed to make better use of the narrow strip of land restricted by the road junction. In terms of structure, the external walls of the building are made of plastered red brickwork with columns and beams of reinforced concrete. Lui Seng Chun is regarded as the representative of "Kee-lau" of the pre-war period in Hong Kong.

Following the completion of basic repair works on Lui Seng Chun in 2005, AMO com-

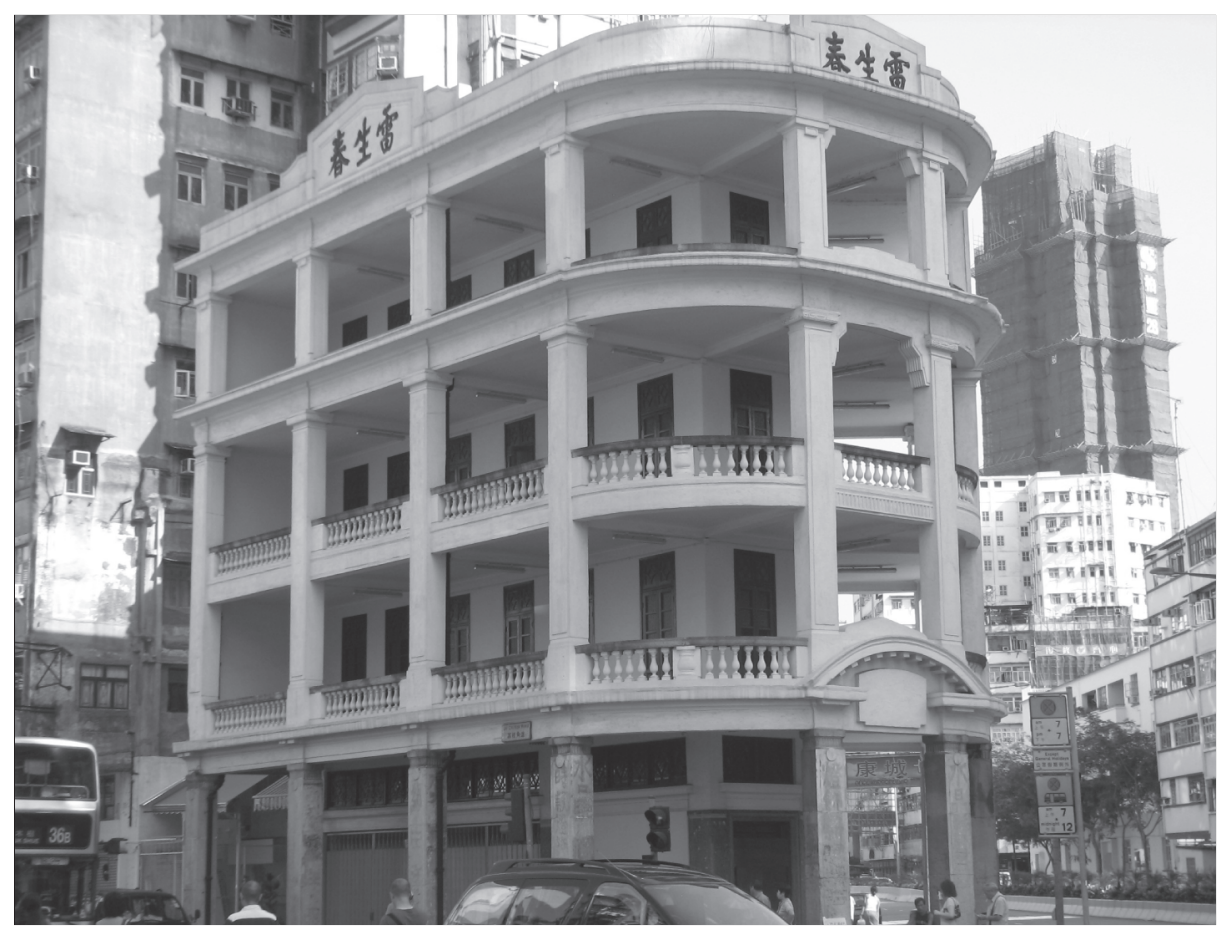

Figure 2. Lui Seng Chun 
missioned a consultancy study on its potential for adaptive reuse and sustainable development. The consultancy study is to take into account a series of relevant factors, including its historical background and building structure, district characteristics, transportation and tourism attractiveness etc. when drawing up possible adaptive reuse proposals. Liu Seng Chun is registered as a Grade I historic building in Hong Kong, but sadly this does not guarantee its preservation (Sunday Morning Post, 2007).

\subsection{Application of the ARP model to Lui Seng Chun}

Lui Seng Chun was constructed in 1932. Its current building age is therefore 75 years. The physical life is estimated conservatively at 100 years. The useful life of the building is determined by "discounting" the physical life by expected obsolescence, comprising physical, economic, functional, technological, social and legal criteria.

Physical obsolescence can be measured by an examination of maintenance policy and performance. Useful life is effectively reduced if building elements are not properly maintained. A scale is developed such that buildings with a high maintenance budget receive a $0 \%$ reduction, while buildings with a low maintenance budget receive a $20 \%$ reduction. Interim scores are also possible, with normal maintenance intensity receiving a $10 \%$ reduction. For Lui Seng Chun, maintenance was minimal for most of its life, and it has been left in a state of disrepair more recently, so a score of $20 \%$ has been chosen.

Economic obsolescence can be measured by the location of a building to a city centre or central business district. Useful life is effectively reduced if a building is located in a relatively low populated area. A scale is developed such that buildings sited in an area of high population density receive a $0 \%$ reduction, while buildings sited in an area of low population density receive a $20 \%$ reduction. Interim scores are also possible, with average population density receiving a $10 \%$ reduction. Lui Seng Chun would logically receive a $0 \%$ reduction as it sits in a retail centre in one of the most densely populated areas of Hong Kong.

Functional obsolescence can be measured by determining the extent of flexibility imbedded in a building's design. Useful life is effectively reduced if building layouts are inflexible to change. A scale is developed such that buildings with a low churn cost receive a $0 \%$ reduction, while buildings with a high churn cost receive a $20 \%$ reduction. Interim scores are also possible, with typical churn costs receiving a $10 \%$ reduction. The building being largely open design would attract a low churn cost for alterations, and so a reduction of $5 \%$ has been assumed. No actual data on churn costs exists for this building.

Technological obsolescence can be measured by the building's use of operational energy. Useful life is effectively reduced if a building is reliant on high levels of energy in order to provide occupant comfort. A scale is developed such that buildings with low energy demand receive a $0 \%$ reduction, while buildings with intense energy demand receive a $20 \%$ reduction. Interim scores are also possible, with conventional operating energy performance receiving a $10 \%$ reduction. The building has a small narrow floor plan with high ceilings, significant ventilation openings and large covered balconies all around. It has little reliance on mechanical systems for occupancy. A value of $0 \%$ for technological obsolescence has therefore been selected.

Social obsolescence can be measured by the relationship between building function and the marketplace. Useful life is effectively reduced if building feasibility is based on external income. A scale is developed such that buildings with fully owned and occupied space receive a 
$0 \%$ reduction, while buildings with fully rented space receive a $20 \%$ reduction. Interim scores are also possible, with balanced rent and ownership receiving a $10 \%$ reduction. Lui Seng Chun, although starting its life as a shopfront with residence above, has relied since on income obtained through retail or accommodation services. A $20 \%$ reduction is therefore taken.

Legal obsolescence can be measured by the quality of the original design. The rationale for this is that higher quality leads to higher compliance levels against future (usually increasing) statutory requirements. Useful life is effectively reduced if buildings are designed and constructed to a low standard. A scale is developed such that buildings of high quality receive a $0 \%$ reduction, while buildings of low quality receive a $20 \%$ reduction. Interim scores are also possible, with average quality receiving a $10 \%$ reduction. There is no doubt that Lui Seng Chun is solidly built and of a high standard back in 1932, and still today, although some structural rectification work is evident. A 5\% reduction is applicable.

Using this data in the $A R P$ model, useful life $\left(L_{u}\right)$ is calculated as 61 years (Equation 1$)$ and its adaptive reuse potential is $41.6 \%$ (moderate, and decreasing) as determined by Equation $4\left(E L_{b}>E L_{u}\right)$. According to the model, Lui Seng Chun's optimal potential for adaptive reuse was reached in 1993. This is somewhat arbitrary given the chosen value for $\mathrm{L}_{\mathrm{p}}$ is conservative, for at 150 years of physical life the assessed ARP score is high at 52.0\%. For modern buildings, it would be typical to select a physical life less than 100 years. The maximum ARP score possible for Lui Seng Chun is $63.1 \%$ (using Equation 2, where $x=E L_{u}=61$ years). While undoubtedly other projects in Hong Kong could be found to exceed this score, the timing for this project and its heritage value are clearly compelling. Figure 1 (earlier) summarizes the Lui Seng Chun ranking.

\subsection{Multi-criteria analysis}

In the Hong Kong context, given very high land values that prevail, the best decision from a purely financial perspective would be to demolish Lui Seng Chun and construct a highrise tower. Fortunately such action is not available given the current ownership and historical significance. So the remaining options were restricted to original or alternative uses for the current building form.

The next best economic option is retail/tourism. Other uses, such as boutique office space, accommodation or museum would not deliver the same cash flow levels. Yet all of these alternative uses would provide strong social and environmental performance. While use as a shopfront and residence is no longer relevant, the building can be retained for other retail/ tourism activities such as arts and crafts, herbal medicines and therapies, and/or restaurants. The combination of retail space at street level with restaurant space (e.g. traditional teahouse) at each of the upper levels, embodying a display of some of the building's artefacts as decoration, appears credible. For the purpose of this paper, and given a definitive scheme is yet to be determined and approved by the AMO, such an adaptive reuse solution is assumed.

Using SINDEX, the four criteria described earlier are assessed. Figure 3 indicates the sustainability index for Lui Seng Chun is 3.25, based on a balanced combination of all criteria.

As this score is in excess of 1 and all criteria benchmarks are achieved, the proposed redevelopment appears a wise decision. The sustainability index rises to 3.49 when the decision is based solely on economic criteria, and falls to 3.01 when the decision is based solely on social criteria, indicated strong performance in both areas. A sustainability index around 3 is a good result (scores above 5 are rare). Figures 4, 5, 6 and 7 summarized the base data used in the evaluation. 


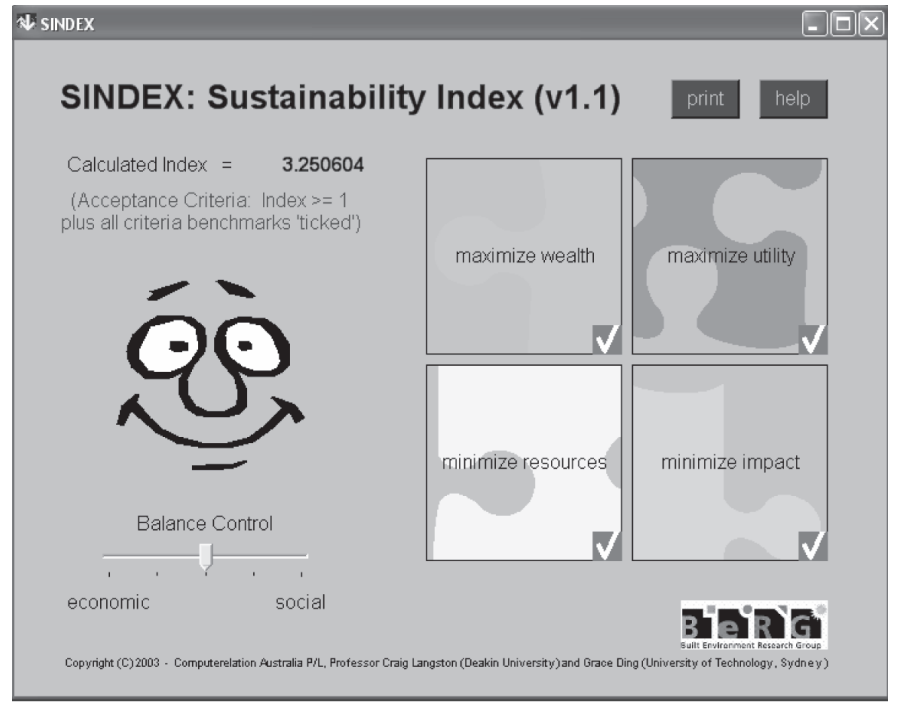

Figure 3. SINDEX summary page

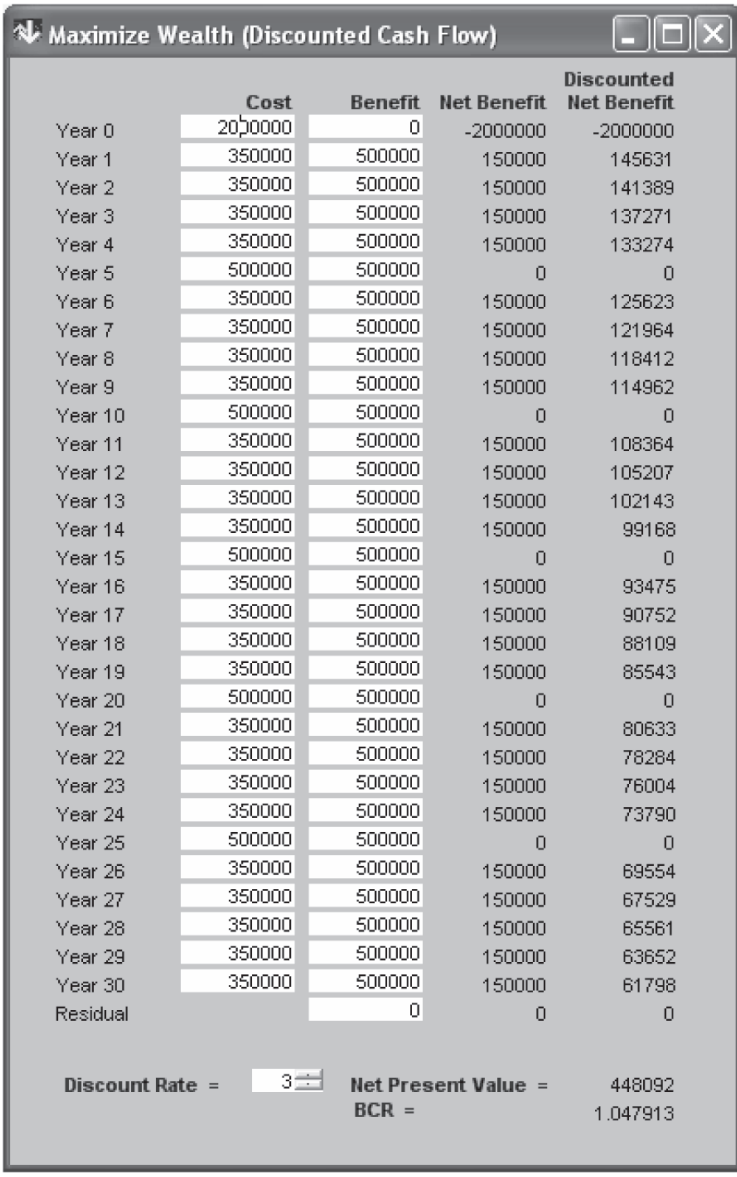

Figure 4. Maximize wealth input screen
Notes:

1. All values are expressed in $\mathrm{HK} \$$ in today's terms (2007) as the adopted discount rate is net of inflation.

2. The building was donated to AMO and has no purchase or residual value.

3. A refurbishment cost of $\mathrm{HK} \$ 2$ million has been estimated.

4. The rent expectation for the building is $\mathrm{HK} \$ 200 / \mathrm{m}^{2}$ per month as an average across ground and upper floor net rentable areas assuming full tenancy.

5. Annual expenditure includes wages operational costs for tenants.

6. Major repair activities are budgeting every 5 years.

7. Analyses greater than 30 years do not significantly affect NPV or BCR calculations. 


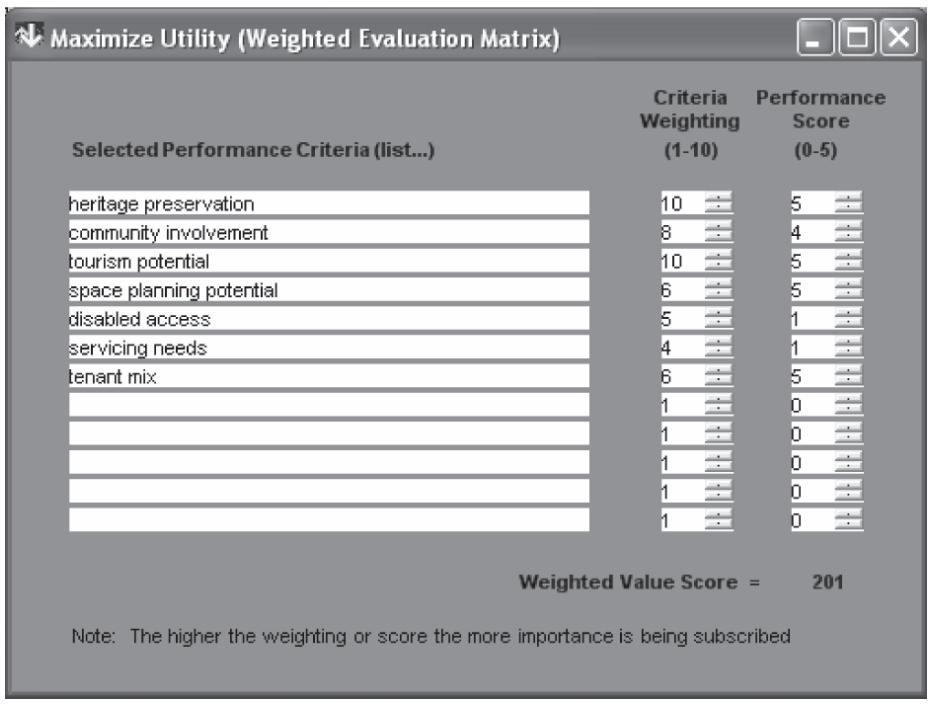

Figure 5. Maximize utility input screen

Notes:

1. Heritage preservation through an economically sustainable activity is sought.

2. Building egress and access is a problem.

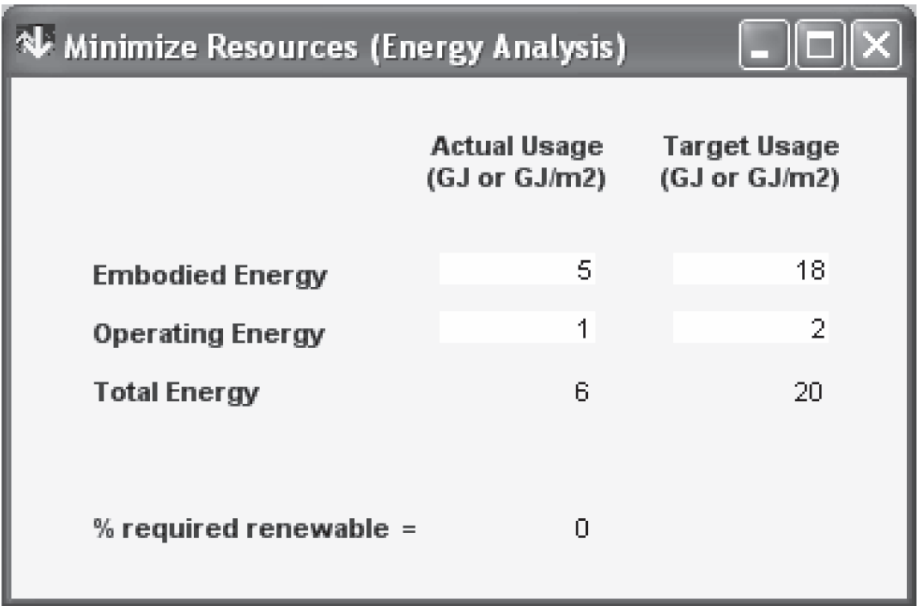

Figure 6. Minimize resources input screen

Notes:

1. Energy figures are annual.

2. Embodied energy relates only to the refurbishment works.

3. Minimal operating energy demand is expected (i.e. no air conditioning).

4. Targets are based on typical Hong Kong practices. 


\section{DISCUSSION}

The previous investigation of the potential redevelopment of Lui Seng Chun in Hong Kong validates the decision to pursue an adaptive reuse strategy. This does not, of itself, validate the approach described in this paper, but does provide some evidence for its application to practice. It also demonstrates that such an approach is appropriate for use by practitioners without the need for highly specialized skills. Further research is underway in both Australia and Hong Kong to further test the validity and refine the ARP model in practice.

\begin{tabular}{|c|c|c|c|}
\hline Nh Minimize Impact (Risk Assessment Questionnaire) & 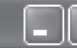 & $\square$ & $x$ \\
\hline Manufacture & & YES & \\
\hline Does the manufacturer have an environmental management plan? & & Г & \\
\hline Are new raw materials a renewable resource? & & $\sqrt{\square}$ & \\
\hline Does the manufacturing process involve hazardous materials? & & 厂 & \\
\hline During manufacture, are greenhouse gas enissions minimal? & & $\sqrt{ }$ & \\
\hline Does the manufacturing process generate untreated pollution? & & 厂 & \\
\hline Are product components manufactured from recycled materials? & & $\sqrt{\square}$ & \\
\hline Are the majority of raw materials imported from overseas? & & 厂 & \\
\hline Is manufacturing waste sent to landfill? & & Г & \\
\hline Are significant amounts of manufacturing waste recycled? & & $\sqrt{\checkmark}$ & \\
\hline Are most products packaged? & & Г & \\
\hline Design & & & \\
\hline Is environmental performance a specific design abjective? & & $\sqrt{\square}$ & \\
\hline Were outcomes evaluated using a life-cost approach? & & $\sqrt{\checkmark}$ & \\
\hline Was enbodied energy considered in the decision process? & & $\sqrt{\square}$ & \\
\hline Are there significant heritage implications to be considered? & & $\sqrt{\checkmark}$ & \\
\hline Construction & & & \\
\hline Will the construction process generate untreated pollution? & & Г & \\
\hline Will environmental inpacts during construction be monitored? & & $\sqrt{4}$ & \\
\hline Will construction waste be prinarily recycled? & & $\sqrt{\checkmark}$ & \\
\hline Usage & & & \\
\hline Does the intended function use water efficiently? & & $\Gamma$ & \\
\hline Mill pollutants be discharged directly into the environment? & & $\Gamma$ & \\
\hline Is waste recycled? & & $\sqrt{\checkmark}$ & \\
\hline Are significant energy minimization strategies in place? & & $\sqrt{6}$ & \\
\hline Is noise transmitted to surrounding spaces? & & Г & \\
\hline Demolition & & & \\
\hline Are most demolished materials recyclable? & & $\sqrt{\nabla}$ & \\
\hline Does non-recyclable waste involve hazardous materials? & & & \\
\hline Are all components sent to landfill biodegradable? & & & \\
\hline Has a deconstruction plan been developed? & & & \\
\hline Context (optional) & Ono & & \\
\hline Is the site in a remote location? & & $\Gamma$ & \\
\hline Is the site environmentally-sensitive or protected? & & $\sqrt{\square}$ & \\
\hline Was an environinental impact statement prepared for the project? & & & \\
\hline Are there rare or endangered species near the site? & & & \\
\hline Will the site's natural features be significantly disturbed? & & Г & \\
\hline Is site stability and erosion control a particular abjective? & & & \\
\hline Are affected site areas reinstated upon completion of construction? & & Г & \\
\hline Risk Assessment = & moder & rate & \\
\hline
\end{tabular}

Figure 7. Minimize impact input screen

Notes:

1. The building is expected to have a small ecological footprint. 
A sensitivity analysis of the results shows that they are not easily influenced by different assumptions. The main benefits of Lui Seng Chun lie in its low embodied energy (resulting from the reuse of materials already in place) and its relatively high community values. Nothing special was assumed in terms of environmental performance, and the score could have been further improved if this was more of a priority.

Lui Seng Chun is considered to have at least 25 years of physical life remaining. Whether it can support a financially viable enterprise over this time remains to be seen. Should circumstances change that make its anticipated use redundant, further adaptive reuse potential may still exist.

Interestingly, if the building's physical life were reset to 25 years following the proposed revitalization, the ARP model would indicate another 15 years of useful life ahead. This must give additional confidence to the actions taken to preserve the building for the people of Hong Kong.

\section{CONCLUSION}

A valuable component in the holistic assessment of the contribution individual buildings can make to the communities in which they are sited is their potential for reuse once their original useful life has concluded. Providing a means for calculating this potential is important. Use of the ARP model to identify potential, and the subsequent evaluation of the full effects of buildings, needs to be possible to properly consider the true benefits of adaptive reuse. In time such an approach will ensure that buildings with significant remaining capacity to serve our society will be retained and given a new breath of life. In this way, and only in this way, can we ever hope to achieve even a modest level of sustainability in the built environment.
This research demonstrates in a practical way how projects with significant "embedded physical life" can be identified and evaluated objectively. The study of the historic Lui Seng Chun project in Hong Kong validates current decisions not to demolish this building, and to look for an adaptive reuse solution that adds community value. Therefore using a more balanced and sustainable approach to development a richer and more lasting contribution to society can be made.

\section{REFERENCES}

Anon. (Anonymous) (2006) Sustainable Solar Solutions Case Study 02, Sustainability Victoria, Melbourne, 3, http://www.sustainability.vic. gov.au/www/html/1589-case-studies.asp.

Abbotts, J., Ertell, K. B., Leschine, T. M. and Takaro, T. K. (2003) Building Leasing at the Department of Energy's Hanford Site: Lessons Learned from Commercial Reuse. Federal $\mathrm{Fa}$ cilities Environmental Journal, Spring, p. 95107.

Abelson, P. W. (1996) Project Appraisal and Valuation of the Environment: General Principles and Six Case-Studies in Developing Countries, MacMillan.

Ball, R. (1999) Developers, regeneration and sustainability issues in the reuse of vacant industrial buildings. Building Research and Information, 27(3), p. 140-148.

Beinat, E. and Nijkamp, P. eds. (1998) Multicriteria Analysis for Land-use Management, Kluwer Academic Publishers.

Bell, S. and Morse, S. (1999) Sustainability Indicators: Measuring the immeasurable? Earthscan Publications.

Brandt, M. (2006) How to adaptively reuse a community asset? Heritage: the magazine of the Heritage Canada Foundation, 9(2), p. 21-22.

Chen, M. J. and Huang, G. H. (2001) A derivative algorithm for inexact quadratic program - application to environmental decision-making under uncertainty. European Journal of Operational Research, 128(3), p. 570-586.

Chusid, M. (1993) Once is Never Enough. Building Renovation, Mar-Apr, p. 17-20. 
Ding, G. and Langston, C. (2002) A Methodology for Assessing the Sustainability of Construction Projects and Facilities, in Proceedings of ICEC $3^{\text {rd }}$ World Conference, Melbourne.

Ding, G. and Langston, C. (2004) Multiple criteria sustainability modelling: case study on school buildings. International Journal of Construction Management, 4(2), p. 13-26.

Doak, J. (1999) Planning for the reuse of redundant defence estate: disposal processes, policy frameworks and development impacts. Planning Practice and Research, 14(2), p. 211-224.

Gallent, N., Howet, J. and Bellt, P. (2000) New uses for England's old airfields. Area, 32(4), p. 383394.

Gallus, C. and Langston, C. (2006) Increasing the Environmental Performance of Property Developments: A Developer's Perspective, Proceedings of the $31^{\text {st }}$ Australasian University Building Educators Association Conference (AUBEA 2006), Faculty of Design Architecture and Building, University of Technology Sydney, Australia, pp. 1-15,

Guy, S. and Kibert, C. J. (1998) Developing indicators of sustainability: US experience. Building Research and Information, 26(1), p. 39-45.

Hanley, N. (1992) Are there environmental limits to cost benefit analysis? Environmental \& Resource Economics, 2(1), p. 33-59.

Harrington, L., Foster, R., Wilkenfeld, G., Treloar, G. J., Lee, T. and Ellis, M. (1999) Baseline Study of Greenhouse Gas Emissions from the Australian Residential Building Sector to 2010, for the Australian Greenhouse Office, Canberra, February, 157.

Kenny, M. and Meadowcroft, J. eds. (1999) Planning Sustainability, Routledge.

Khan, F. I., Sadiq, R., and Husain, T. (2002) Green Pro-I a risk based life cycle assessment and decision making methodology for process plant design. Environment Modelling \& Software, 17(8), p. 669-692.

Langston, C., Wong, F., Hui, E. and Shen, L. Y. (2007) Strategic assessment of building adaptive reuse opportunities in Hong Kong. Building and Environment (under review).

Langston, C. (2005) Life-cost Approach to Building Evaluation, Elsevier.

Langston, C. and Ding, G. (2001) Sustainable Practices in the Built Environment (Second Edition), Butterworth-Heinemann.
Langston, C. and Lauge-Kristensen, R. (2002) Strategic Management of Built Facilities, Butterworth-Heinemann.

Leone, A. (2003) Late Antique North Africa: production and changing use of buildings in urban areas. Al-Masaq, 15(1), p. 21-33.

Maggs, A. (1999) Adaptive reuse. In place, 1(4), p. 33-34.

McCornell, R. L. and Abel, D. C. (1999) Environmental Issues: Measuring, analysing and evaluating, Prentice Hall.

McLaren, P. (1996) Adaptation and reuse, Monuments and sites Australia: Australia ICOMOS: Sri Lanka National Committee of ICOMOS, p. $170-176$.

Meillaud, F., Gay, J. B. and Brown, M. T. (2005) Evaluation of a building using the emergy method. Solar Energy, 79(2), p. 204-212.

Newman, H. K. (2001) Historic preservation policy and regime politics in Atlanta. Journal of Urban Affairs, 23(1), p. 71-86.

Nijkamp, P., Rietveld, P. and Voogd, H. (1990) Multicriteria Evaluation in Physical Planning, North-Holland.

Poon, B. H. S. (2001) Buildings recycled: city refurbished. Journal of Architectural Education, 54(3), p. 191-194.

Rees, W. E. (1999) The built environment and the ecosphere: a global perspective. Building Research and Information, 27(4/5), p. 206-220.

RVD (2007) Hong Kong Property Review, Rating and Valuation Department, The Government of the Hong Kong Special Administrative Region (http://www.rvd.gov.hk/en/publications/ hkpr07.htm).

Sunday Morning Post (2007) Hong Kong newspaper, Sunday July 8 (http://www.scmp.com/por$\mathrm{t} \mathrm{a} \mathrm{l/s} \mathrm{i} \mathrm{t} \mathrm{e} \mathrm{/} \mathrm{S} \mathrm{C} \mathrm{M} \mathrm{P/m} \mathrm{e} \mathrm{n} \mathrm{u} \mathrm{i} \mathrm{e} \mathrm{m} \mathrm{.}$ $2 \mathrm{c} 913216495213 \mathrm{~d} 5 \mathrm{df646910 \textrm {cba0a0a0/ }}$ ?vgnextoid $=74$ d c b 23 e 0 f 1 a $3110 \mathrm{VgnV}$ C M 10000036 a 0 a 0 a R C R D \& vgnextfmt=teaser\&s=News).

The Standard (2007) Hong Kong newspaper, Saturday-Sunday February 17-18 (http:// www.thestandard.com.hk/news_detail.asp? pp_cat $=11 \&$ art_id $=38548 \&$ sid $=12269160 \&$ con_ type $=1+$ ).

Tully, E. (1993) Construction Employment Multipliers to take account of Price Increases between 1983 and 1992, Department of Industry, Science and Technology, Canberra. 
Van Driesche, J. and Lane, M. (2002) Conservation through conversation: collaborative planning for reuse of a former military property in Sauk County, Wisconsin. Planning Theory and Practice, 3(2), p. 133-153.
Van Pelt, M. J. F. (1993) Ecological Sustainability and Project Appraisal, Averbury.

Vignes, R. P. (1999) Limited life cycle analysis: a tool for the environment decision making toolbox. Strategic Environment Management, 1(4), p. 297-332.

\section{SANTRAUKA}

\section{POTENCIALAUS NAUDOJIMO MODELIO}

\section{TAIKYMAS HONKONGE: LUI SENG CHUN ATVEJO TYRIMAS}

\section{Craig LANGSTON, Li-Yin SHEN}

Priimant sprendimus dèl nuosavybės portfelio, kyla vis sudėtingesnių ir tarpusavyje labiau susijusių klausimų. Šiame darbe nagrinëjami ryšiai tarp finansinių, aplinkos ir socialinių parametrų, susijusių su pastatų naudojimu. Naujas modelis, numatantis potencialų pastatų naudojimą, taikomas Honkonge esančiam paveldo pastatui, vadinamam Lui Seng Chun. Transformuojant pastatų ir nuosavybės industriją, kai siekiama darnesnių praktikos, strategijų ir rezultatų, šis modelis gali būti naudingas, nes suteiks priemonių, padėsiančių identifikuoti ir klasifikuoti tuos pastatus, kurių naudojimo potencialas didelis. Honkongo atveju tai galimybe imtis darnaus, atsakingo energijos ir gamtinių išteklių valdymo, nes galima nustatyti ir įvertinti besaikio bei netinkamo išteklių naudojimo problemas ir įdiegti reikiamas vadybos strategijas. Atsižvelgiant ì pastato amžių ir būklę, Lui Seng Chun fiziškai dar gali gyvuoti bent 25 metus. Toliau naudojamas daugiakriterinio darnos vertinimo įrankis patvirtina išvadą, kad naudojimo strategija šiame pastate nemenkai prisidès prie viso Honkongo ekonominio, socialinio ir aplinkos patrauklumo. Rekomenduojama taikyti šiuos metodus kitiems pastatams valdyti, kurių likusi naudojimo trukme dar yra netrumpa. 